University of Nebraska - Lincoln

DigitalCommons@University of Nebraska - Lincoln

2003

\title{
Capture of Breeding and Wintering Shorebirds with Leg-Hold Noose-Mats
}

Katherine R. Mehl

Texas A \& M University - Kingsville, k_mehl@ducks.ca

Kiel L. Drake

University of Saskatchewan

Gary W. Page

Point Reyes Bird Observatory

Peter M. Sanzenbacher

U.S. Geological Survey

Susan M. Haig

U.S. Geological Survey, Susan_Haig@usgs.gov

See next page for additional authors

Follow this and additional works at: https://digitalcommons.unl.edu/usgsstaffpub

Mehl, Katherine R.; Drake, Kiel L.; Page, Gary W.; Sanzenbacher, Peter M.; Haig, Susan M.; and Thompson, Jonathan E., "Capture of Breeding and Wintering Shorebirds with Leg-Hold Noose-Mats" (2003). USGS Staff -- Published Research. 679.

https://digitalcommons.unl.edu/usgsstaffpub/679

This Article is brought to you for free and open access by the US Geological Survey at DigitalCommons@University of Nebraska - Lincoln. It has been accepted for inclusion in USGS Staff -- Published Research by an authorized administrator of DigitalCommons@University of Nebraska - Lincoln. 
Authors

Katherine R. Mehl, Kiel L. Drake, Gary W. Page, Peter M. Sanzenbacher, Susan M. Haig, and Jonathan E. Thompson 


\title{
Capture of breeding and wintering shorebirds with leg-hold noose-mats
}

\author{
Katherine R. Mehl, ${ }^{1,4}$ Kiel L. Drake, ${ }^{1,5}$ Gary W. Page, ${ }^{2}$ Peter M. Sanzenbacher, ${ }^{3}$ \\ Susan M. Haig, ${ }^{3}$ and Jonathan E. Thompson ${ }^{1,6}$ \\ ${ }^{1}$ Caesar Kleberg Wildlife Research Institute, Texas A\&M University-Kingsville, MSC 218, \\ 700 University Boulevard, Kingsville, Texas 78363 \\ 2 Point Reyes Bird Observatory, 4990 Shoreline Highway, Stinson Beach, California 94970 USA \\ ${ }^{3}$ USGS Forest \& Rangeland Ecosystem Science Center, 3200 SW Jefferson Way, Corvallis, Oregon 97331 USA
}

Received 20 August 2002; accepted 27 January 2003

\begin{abstract}
Development of effective trapping techniques is important for conservation efforts, as marking and subsequent monitoring of individuals is necessary to obtain accurate estimates of demography, movements, and habitat use. We describe a leg-hold noose-mat trap for capturing breeding and nonbreeding shorebirds. Using this method, we trapped 50 Piping Plovers (Charadrius melodus), 2258 Snowy Plovers (C. alexandrinus), 38 Killdeers (C. vociferus), and 64 Dunlins (Calidris alpina) in the western and southern United States. The trap was lightweight, making it easy to transport and set up. It was effective on unvegetated substrates at both coastal and inland sites and could be modified for a variety of habitats. Furthermore, this trap allowed researchers to target specific groups of birds including territorial individuals. Easy removal of birds from traps minimized handling time, stress, and injury.
\end{abstract}

SINOPSIS. Captura de aves playeras en reproducción o invernando con toldos de lazos para atrapar las patas

El desarrollo de técnicas efectivas para atrapar aves es importante para los esfuerzos para conservarlas, ya que marcar y el monitoreo subsiguiente de los individuos es necesario para obtener estimados razonables de la demografía, de los movimientos y del uso del hábitat. Describimos un toldo con lazos para atrapar las patas para capturar aves playeras anidantes y no-anidantes. Se atraparon 50 Charadrius melodus, 2258 C. alexandrinus, 38 C. vociferus y 64 Calidris alpina tilizando este método a través del oeste y del sur de los Estados Unidos de Norte América. La trampa fué liviana, haciéndola facil de transportar y de preparar. Fué efectiva en sustratos sin vegetación en localidades tanto costaneras como internas y puede ser modificada para su uso en varios hábitats. Más aún, esta trampa permitió que los investigadores enfocaran en grupos específicos de aves, incluyendo aves territoriales. La facilidad para remover las aves de las trampas minimizó el tiempo de manipulación, la tensión y los daños físicos a estas.

Key words: breeding, Calidris, Charadrii, noose-carpets, shorebird, trapping techniques, wintering

Understanding the processes affecting avian population dynamics requires marking and tracking birds (Nichols and Kaiser 1999; White and Burnham 1999; Webster et al. 2002). For instance, mark-recapture methods are necessary to gain reliable estimates of survival, population size and growth, and probabilities of dispersal (White and Burnham 1999). Most often, stud-

${ }^{4}$ Corresponding author. Current address: Ducks Unlimited Canada, 562 Water Street, St. Johns, Newfoundland A1E 1B7, Canada. Email: k_mehl@ ducks.ca

${ }^{5}$ Current address: Department of Biology, University of Saskatchewan, 112 Science Place, Saskatoon, Saskatchewan S7N 5E2, Canada.

${ }^{6}$ Current address: Ducks Unlimited Canada, \#200 10720-178th Street, Edmonton, Alberta T5S 1J3, Canada. ies focus on breeding birds; however, information on survival, habitat use, and movements are equally critical for wintering birds.

Few studies of marked individuals have been carried out on wintering shorebirds, in part, because capturing them can be challenging and laborious (Lyons and Haig 1995; Warnock et al. 1995; Dierschke 1998). Factors complicating trapping efforts include target species behavior, annual cycle (nesting or non-nesting), habitat type, and unfavorable environmental variables (e.g., strong winds and precipitation). For example, wintering birds are not constrained to specific sites (i.e., nests) where researchers can focus trapping efforts. Trapping methods that overcome these constraints and increase trapping success of shorebirds will aid researchers in understanding life histories and habitat requirements. 
In this paper, we report the use of a leg-snare trap, hereafter noose-mat (Bub 1991), to capture Piping Plovers (Charadrius melodus) and Snowy Plovers ( $C$. alexandrinus) wintering along the south Texas coast (Drake 1999; Drake et al. 2001), Killdeers (C. vociferus) and Dunlins (Calidris alpina) wintering in the Willamette Valley of Oregon (Sanzenbacher and Haig 2002a,b), and breeding and wintering Snowy Plovers within coastal and interior California (Page et al. 1983, 1995; Stenzel et al. 1994). Mist-netting, the most common method of capturing shorebirds, was ineffective in these studies due to wind, precipitation, and wariness of the study species. Spot-lighting (Knopf and Rupert 1995) was also ineffective. Noose-mats provided a successful method of trapping and allowed us to target the desired species or individuals during both breeding and wintering periods. We describe this trapping technique used in different habitats throughout varying phases of the annual cycle.

\section{METHODS}

Study areas. Studies of wintering Piping and Snowy plovers took place on South Padre Island $\left(26^{\circ} 10^{\prime} \mathrm{N}, 97^{\circ} 10^{\prime} \mathrm{W}\right)$, and on adjacent mainland tidal flats of southern Texas, from 10 August 1997 to 29 March 1998. Judd et al. (1977) provide detailed descriptions of the study area. Wintering Killdeers and Dunlins were studied in 1999 and 2000 in the Willamette Valley of Oregon $\left(45^{\circ} \mathrm{N}, 123^{\circ} \mathrm{W}\right)$, an agricultural landscape approximately $60 \mathrm{~km}$ from the Pacific Coast. Hulse (1998) provides a more detailed description of the region. Studies of breeding and wintering Snowy Plovers took place in California between 1977 and 2001. See Page et al. (1983), Page et al. (1995), and Stenzel et al. (1994) for a description of study areas in California.

Traps. Noose-mats consisted of monofilament nooses (fishing line) attached to mats of wire mesh (often sold as hardware cloth). Mats were made from sheets of $6-\mathrm{mm}$ to $13-\mathrm{mm}$ wire mesh ranging in size from $0.30 \mathrm{~m} \times 0.75 \mathrm{~m}$ to $0.10 \mathrm{~m} \times 0.90 \mathrm{~m}$. Using pliers, we bent or clipped leading edges of wire mesh to eliminate sharp edges that might injure birds. In some cases, we spray-painted mats prior to noose attachment to match substrate color at trap sites.

We constructed nooses using 3.63-kg test
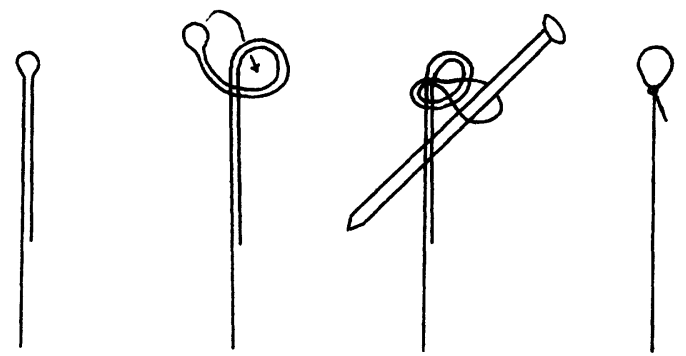

Fig. 1. Tie a single loop at one end of the monofilament line, leaving a small tab $(3-5 \mathrm{~mm})$ at the base of the single loop.

monofilament fishing line. We tied a single loop on one end of the monofilament line (Fig. 1) and then passed the opposite, free end of the line through the single loop to create a noose. We then attached nooses to the wire mat by passing the free, unknotted end of the noose under a crisscross of wire on the mat, tying it in place using a uni-knot that is commonly used to tie fishing lures. We tightened the attached knot by inserting a pencil through the noose and pulling away from the trap (Berger and Mueller 1959; Bub 1991). We tied the slipknot so that nooses opened and closed freely and left a small tab (3-5 mm; Fig. 1) which, when pulled, loosened the slipknot and allowed for quick removal of a captured bird's leg from the trap. Several different noose sizes were tested to maximize capture efficiency. In Texas, nooses standing at chest height of a bird worked best (e.g., about $6 \mathrm{~cm}$ for Piping Plovers). Nooses used in California and Oregon were about $4 \mathrm{~cm}(1.5 \mathrm{in})$ in diameter when fully open. In all cases, it was critical that nooses stood upright, with the opening of the noose parallel to the length, as opposed to the width, of the wire mat (Fig. 2). Gluing the knots that held nooses to the mats helped to keep them upright. We tied several rows of nooses to each wire mat, with individual nooses attached at intervals of about $6 \mathrm{~cm}$, depending upon noose size. In general, nooses should be spaced close enough to prevent gaps between adjacent nooses while far enough apart that nooses do not overlap one another.

When trapping nonbreeding Piping and Snowy Plovers in Texas, we used lead fences consisting of chicken wire $\left(3 \mathrm{~cm}^{2}\right)$ about $0.3 \mathrm{~m}$ in height and $2 \mathrm{~m}$ in length (Fig. 2). To anchor the fence into the substrate, we wove three alu- 


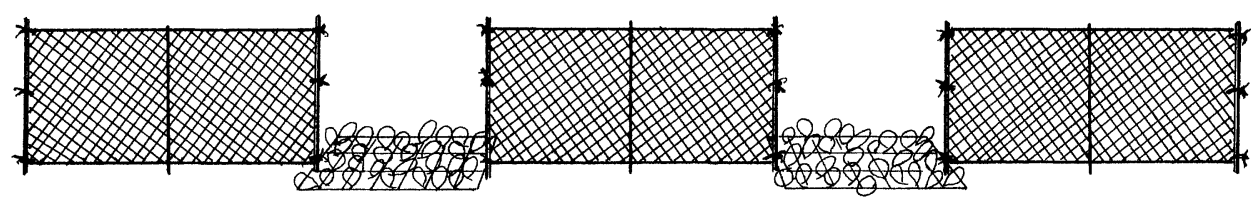

Fig. 2. Positioning of lead fences and noose-mats to capture wintering shorebirds.

minum rods perpendicular to the length and extending about $0.2 \mathrm{~m}$ beyond the lower edge of the chicken wire. We did not camouflage lead fences.

Trapping procedures. We used several trapping approaches depending on the target species, habitat, and annual cycle. In Texas, we placed traps at sites with foraging birds. Since birds generally foraged into the wind, we positioned noose-mats and lead fences perpendicular to the wind. Alternating lead fences and noose-mats created a barrier across the foraging habitat (Fig. 2). Rather than fly over, birds walked along the leads and were snared when they crossed noose-mats. In Oregon and California, we trapped wintering plovers by laying multiple noose-mats end to end, sometimes in staggered rows, and anchoring them to the ground with wire stakes. If birds did not approach the traps, observers slowly advanced toward birds and attempted to herd them into the trap area. To capture wintering Dunlins, we identified fields consistently used for foraging and noted the time of day they were present. We then focused our efforts near areas with ponded water where birds returned each day at dusk. We set out multiple noose-mats at the site prior to their arrival.

At Snowy Plover breeding sites, nests were surrounded with noose-mats in a triangular pattern (Fig. 3) and anchored with metal or wooden stakes to prevent snared birds from dragging traps over nests. This arrangement forced birds to cross traps as they returned to incubate nests. In sandy areas, we sometimes applied gentle pressure while moving noose-mats back and forth to submerge the wire mesh in the substrate, leaving only nooses exposed above the sand. In all cases, we remained as close to the traps as target birds would permit and immediately removed snared birds.

\section{RESULTS AND DISCUSSION}

We captured 50 Piping Plovers, 2258 Snowy Plovers (2227 in California, 31 in Texas), 38
Killdeers, and 64 Dunlins with leg-hold noosemats during multiple studies of breeding and wintering shorebirds. Birds did not appear to recognize noose-mats as a threat, as most individuals crossed them with little hesitation. A particular advantage of this trap is that it allows the investigator to target specific individuals, groups, or species. Using noose-mats, we captured territorial Piping Plovers during the nonbreeding season by setting traps within their defended area, as well as individual Snowy Plovers that had become oiled during a spill.

Over time, some Texas birds became wary of trap sites with lead fences and took flight when these obstacles were encountered. With lead fences removed, the noose-mats alone did not appear to deter birds; however, trapping without lead fences required greater capture time because it was more difficult to direct birds over the traps. Other factors that increased capture success included size of target flock and number of traps used. For example, we targeted wintering Killdeers in loose flocks of 15-320 birds and captured up to nine birds in a 5 -h period using 13-20 noose-mats. Further, using 20 noose-mats, we captured as many as 20 Dunlins at a time as they arrived at foraging sites in flocks of 500-8000 birds.

Materials used to construct noose-mats are inexpensive; however, it can take several hours to construct a single mat. Additionally, noosemats required careful handling and frequent maintenance to ensure optimal trap function. Flattened or tangled nooses reduced trapping success. Also, over time, salt water in coastal areas and mud at inland areas encrusted monofilament nooses and caused them to lie flat or not close properly. When these problems occurred, we replaced problematic nooses. Placing noose-mats in cardboard boxes (boxes from a floral shop) and stacking them together reduced entanglement and allowed for easy transportation of traps.

Bird injuries are a risk with any trapping 


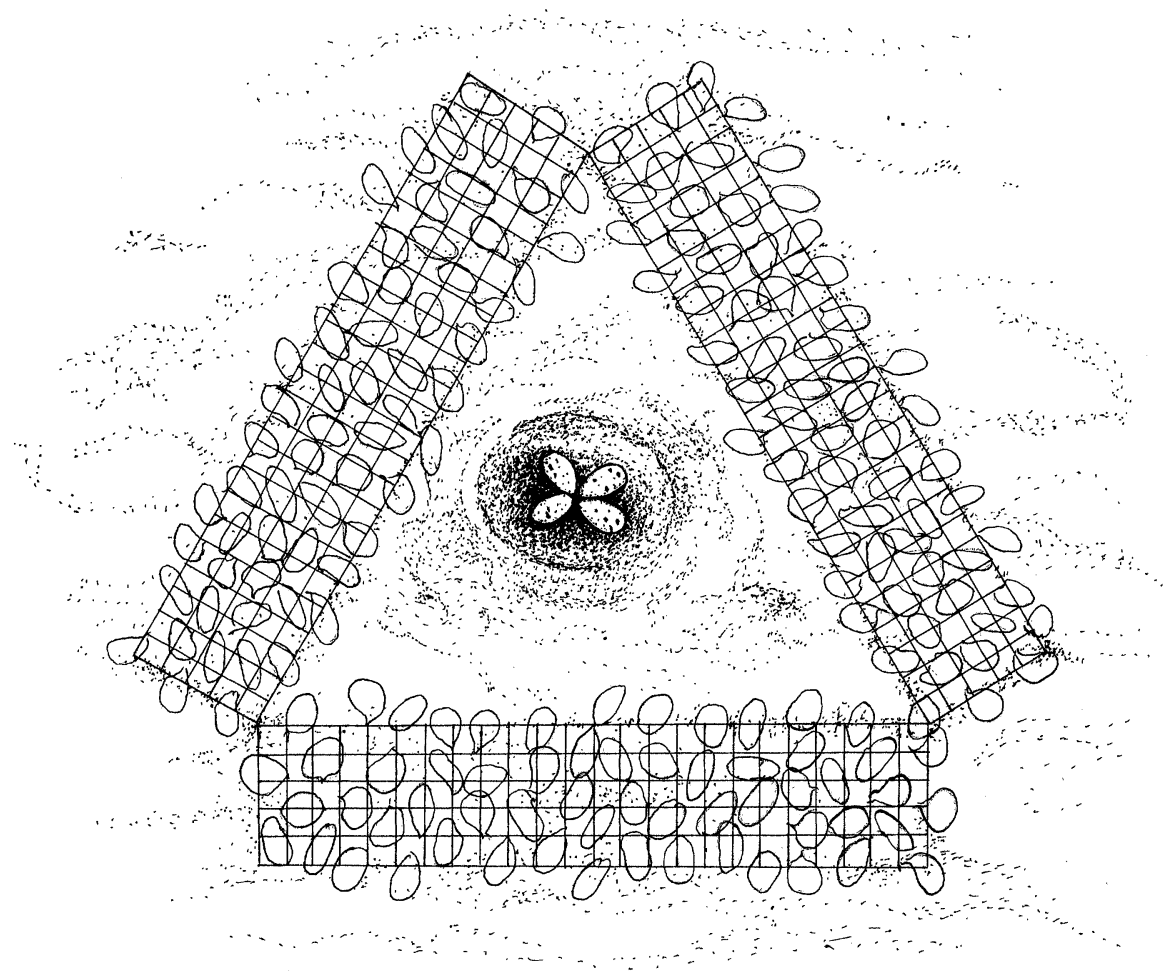

Fig. 3. Positioning of noose-mats to capture breeding shorebirds.

method. Injuries due to noose-mats were rare with a total of three leg injuries across all studies $(0.12 \%, N=2410)$. Other hazards included occasional muddied birds and one mortality that occurred when a Loggerhead Shrike ( $L a-$ nius ludovicianus) killed a Snowy Plover within seconds of its capture. Constant observations of traps and prompt removal of birds upon capture minimize these risks.

In summary, noose-mat traps proved useful in different habitats and on different species. These traps are lightweight and simple to transport. Easy removal of snared birds minimizes handling time and stress on birds. Thus, we consider this trapping method an efficient and important tool for future studies of shorebirds.

\section{ACKNOWLEDGMENTS}

We thank the numerous agencies and groups that provided assistance with our studies. In Texas, Laguna Atascosa National Wildlife Refuge and Caesar Kleberg Wildlife Research Institute at Texas A\&M UniversityKingsville provided logistical support. Additionally, the Interagency Coordination Team of the Southern Laguna Madre, U.S. Army Corps of Engineers, and the U.S.
Fish and Wildlife Service provided funding. For studies in Oregon, the USGS Forest and Rangeland Ecosystem Science Center, U.S. Fish and Wildlife Service, Oregon Department of Fish and Wildlife, and Bureau of Land Management provided funding and logistical support. Numerous individuals assisted with trapping. We thank especially D. Thompson for producing the figures and C. Jackson for earlier draft figures. L. Craig-Moore, C. Gratto-Trevor, S. Hazard, M. Fast, P. Paton, and an anonymous reviewer provided helpful comments that improved the manuscript. This is Caesar Kleberg Wildlife Research Institute manuscript number 02-116.

\section{LITERATURE CITED}

Berger, D. D., ANd H. C. Mueller. 1959. The Balchatri: a trap for the birds of prey. Bird Banding 30: $18-26$.

BuB, H. 1991. Bird trapping and bird banding: a handbook for trapping methods all over the world. Cornell University Press, Ithaca, NY.

DiersChKE, V. 1998. Site fidelity and survival of Purple Sandpipers Calidris maritima at Helgoland (SE North Sea). Ringing and Migration 19: 41-48.

DraKe, K. L. 1999. Time allocation and roosting habitat of sympatrically wintering Piping Plovers ( $\mathrm{Cha}$ radrius melodus) and Snowy Plovers ( $C$. alexandri- 
nus). M.S. thesis. Texas A\&M University-Kingsville, Kingsville, TX.

Drake, K. A., J. E. Thompson, K. L. Drake, and C. ZONICK. 2001. Movements, habitat use, and survival of wintering Piping Plovers. Condor 103: 259-267.

Hulse, D. 1998. Willamette River Basin: a planning atlas. Institute for Sustainable Development, Eugene, OR.

Judd, F. W., R. I. Lonard, And S. L. Sides. 1977. The vegetation of South Padre Island, Texas in relation to topography. Southwestern Naturalist 22: 31-48.

KNOPF, L., AND J. R. RUPERT. 1995. Habits and habitats of Mountain Plovers in California. Condor 97: 743-751.

LYONS, J. E., AND S. M. HAIG. 1995. Fat content and stopover ecology of spring migrant Semipalmated Sandpipers in South Carolina. Condor 97: 427437.

Nichols, J. D., AND A. KaISER. 1999. Quantitative studies of bird movement: a methodological review. Bird Study 46: S289-298.

Page, G. W., L. E. Stenzel, D. W. Winkler, and C. W. Swarth. 1983. Spacing out at Mono Lake: breeding success, nest density, and predation in the Snowy Plover. Auk 100: 13-24.
, M. A. Stern, And P. W. C. Paton. 1995. Differences in wintering areas of Snowy Plovers from inland breeding sites in western North America. Condor 97: 258-262.

SAnzenbacher, P. M., AND S. M. HaIG. 2002a. Regional fidelity and movement patterns of wintering Killdeer in an agricultural landscape. Waterbirds 25: $16-25$.

$\longrightarrow$, AND 2002b. Residency and movement patterns of Dunlin wintering in the Willamette Valley of Oregon. Condor 104: 271-280.

Stenzel, L. E., J. C. Warriner, J. S. Warriner, K. S. Wilson, F. C. Bidstrup, and G. W. Page. 1994. Long-distance breeding dispersal of Snowy Plovers in western North America. Journal of Animal Ecology 63: 887-902.

Warnock, N., G. W. Page, and L. E. Stenzel. 1995. Non-migratory movements of Dunlins on their California wintering grounds. Wilson Bulletin 107: 131-139.

Webster, M. S., P. P. Marra, S. M. Haig, S. BensCh, AND R. T. HOLMES. 2002. Links between worlds: unraveling migratory connectivity. Trends in Ecology and Evolution 17: 76-83.

White, G. C., and K. P. Burnham. 1999. Program MARK: survival estimation from populations of marked animals. Bird Study 46: S120-138. 